\title{
The role of ectomycorrhizal fungi in alleviating pine decline in semiarid sandy soil of northern China: an experimental approach
}

\author{
Jiao-jun ZHU ${ }^{1}$, Feng-qin $\mathrm{LI}^{1}$, Mei-ling XU ${ }^{1,2}$, Hong-zhang $\mathrm{KANG}^{1,3,5}$, Xiang-yun $\mathrm{WU}^{4}$ \\ ${ }^{1}$ Institute of Applied Ecology, Chinese Academy of Sciences, Shenyang 110016, China \\ ${ }^{2}$ Linyi Entry-Exit Inspection \& Quarantine Bureau, Linyi 276000, China \\ ${ }^{3}$ Graduate School of Chinese Academy of Sciences, Beijing 100039, China \\ ${ }^{4}$ University of Engineering \& Technology, Liaoning Province, Fuxin 123000, China \\ ${ }^{5}$ Current institution: College of Agriculture \& Biology, Shanghai Jiaotong University, Shanghai 200240, China
}

(Received 8 April 2007; revised version 19 September 2007; accepted 12 November 2007)

\begin{abstract}
The decline of Mongolian pine (Pinus sylvestris var. mongolica) trees on sandy land in northern China has caused serious ecological concerns. Mongolian pine is an ectomycorrhizal fungus (ECM)-dependent species. Three ECM species (Boletus sp., Lactarius deliciosus and L.sp.) were collected from Mongolian pine plantation stands to test their beneficial effects on Mongolian pine seedlings and their responses to environmental factors such as $\mathrm{pH}$, drought stress and temperature. The results indicated that ECM inoculation significantly increased the rate of ECM colonization and the length of seedling shoots. The three ECM could grow in a $\mathrm{pH}$ range from 4 to 7 , but did not grow under heavy drought stress ( $-1.53 \mathrm{MPa})$. High temperatures (over $37^{\circ} \mathrm{C}$ ) caused death of ECM. When related to soil $\mathrm{pH}$, soil water content and temperature in the Mongolian pine plantations, water conditions and temperature were unfavorable for ECM growth in surface soil, but suitable in deeper soil. Therefore, it was concluded that the failure of natural regeneration in Mongolian pine plantations might be influenced by the lack of ECM in the surface soil because of high temperatures causing ECM death. Moreover, the majority of the root area is distributed in deeper soil, which alleviates the stresses on ECM development and arrests pine decline; this is beneficial for tree growth.
\end{abstract}

Pinus sylvestris var. mongolica / decline / extreme temperature / drought stress / ectomycorrhizal fungi (ECM)

Résumé - Le rôle des champignons ectomycorrhiziens dans la réduction du dépérissement du pin sur sols sableux semi-arides du nord de la Chine : une approche expérimentale. Le dépérissement du Pin de Mongolie (Pinus sylvestris var. mongolica) sur les terres sableuses du nord de la Chine a causé de graves inquiétudes écologiques. Le Pin de Mongolie est une espèce dépendante de champignons ectomycorrhiziens (ECM). Trois espèces de champignons ectomycorrhiziens ont été récoltés (Boletus sp., Lactaria delicious et $L$. sp.) dans des plantations de Pin de Mongolie pour tester leur effet bénéfique sur des semis de Pin de Mongolie et leur réponse aux facteurs environnementaux tels que pH, stress hydrique et température. Les résultats indiquent que l'inoculation d' ECM accroît significativement le taux de colonisation d' ECM et la longueur des pousses des semis. Les trois ECM peuvent croître avec une gamme de $\mathrm{pH}$ allant de 4 à 7, mais ne peuvent pas se développer sous un stress hydrique important ( $-1,53$ MPa). Des températures élevées (au dessus de $37^{\circ} \mathrm{C}$ ) causent la mort de ECM. Relativement au pH du sol, la teneur en eau du sol et la température dans les plantations de Pin de Mongolie, les conditions hydriques et la température étaient défavorables pour la croissance d' ECM à la surface du sol, mais étaient appropriées dans un sol plus profond. Par conséquent, il a été conclu que l'échec de la régénération naturelle dans les plantations de Pin de Mongolie aurait pu être influencé par un manque d' ECM en surface du sol car les températures élevées causent la mort des ECM. En outre, la majorité de la surface racinaire est répartie dans la profondeur du sol, ce qui réduit les contraintes au développement des ECM et arrête le dépérissement des pins, et est favorable à la croissance de l'arbre.

Pinus sylvestris var. mongolica / dépérissement / température extrême / stress hydrique / champignon ectomycorrhizien (ECM)

\section{INTRODUCTION}

Mongolian pine (Pinus sylvestris var. mongolica), a geographical variety of Scots pine (Pinus sylvestris) that is naturally distributed in the Daxinganling Mountain of China (N $50^{\circ} 10^{\prime}-53^{\circ} 33^{\prime}$, E $121^{\circ} 11^{\prime}-127^{\circ} 10^{\prime}$ ') and in Honhuaerji, located in the Hulunbeier sandy plains of China ( $\mathrm{N} 47^{\circ} 35^{\prime}-48^{\circ}$ $36^{\prime}$, E $118^{\circ} 58^{\prime}-120^{\circ} 32^{\prime}$ ) (Fig. 1), is an important candidate tree species for reforestation of semiarid regions with sandy soil $[15,16,41,42]$. Because of its hardy nature and suitability for dry environments, the tree species was first used

*Corresponding author: jiaojunzhu@iae.ac.cn; zrms29@yahoo.com for sand fixation in China in 1955 in the Keerqin sandlands ( $\left.\mathrm{N} 42^{\circ} 43^{\prime}, \mathrm{E} 122^{\circ} 22^{\prime}\right)$. The area of Mongolian pine plantations on sandy land has now reached more than $3.00 \times 10^{5}$ ha in northern China [16, 19, 41] (Fig. 1). Until 1989, these Mongolian pine plantation forests were developing well. However, since 1989, characteristics such as shoot dieback, low growth rate, tree death and failure of natural regeneration have been reported from certain locations in the first trial stands; these factors have resulted in the decline of the Mongolian pine plantation forests in the Keerqin sandlands. Similar phenomena have since been observed successively on a large scale in various sandy soils of northern China [5, 17, 42]. However, 


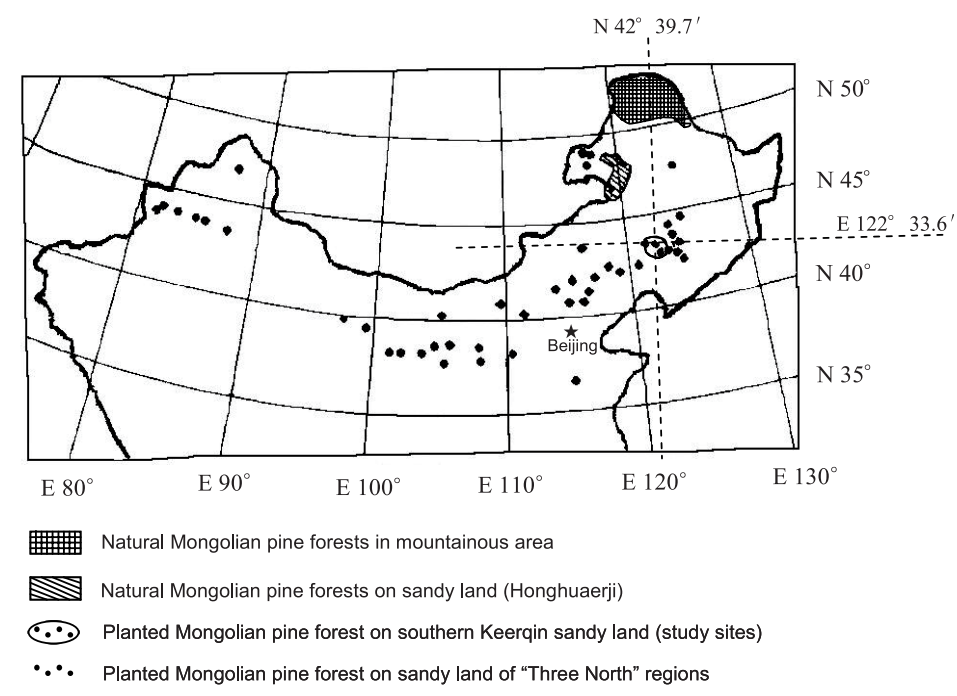

Figure 1. Distribution of Mongolian pine (Pinus sylvestris var. Mongolica) forests in China with the experimental site.

natural forests of Mongolian pine on sandy soil, located in the Hulunbeier sandy plains in China [19, 42], exhibit a very pronounced vigor at the same stage of growth [17, 20,43]. Many hypotheses have been proposed to explain the causes of decline in these plantations, among them nutrient status, water conditions and climatic factors [16, 17, 33, 37, 42], but until now, no specific theory has successfully explained the phenomenon $[11,17,42]$.

In general, ectomycorrhizal symbiosis is ubiquitous on the roots of many plant families such as Pinaceae, Fagaceae and Betulaceae $[27,30]$. Ectomycorrhizal fungi (ectomycorrhizae, ECM) play an important role in the development of forest ecosystems because the dominant tree species in most of the world's temperate and boreal forests are ectomycorrhizal, requiring ECM for the processing of essential phosphorus nutrients $[1,40]$. It is believed that this ECM symbiosis is an adaptation to ecosystems with low mineral nutrient availability [27, $30,31]$. The ECM can enhance the host's nutrient status, not only by increasing the nutrient-absorbing surface area through its extraradical mycelium, but also by accessing nutrients not normally available to plants $[7,30]$. In addition, ECM can protect trees against pathogenic infections, improve the structure of root systems [31] and ameliorate the deleterious effects of heavy metals on the host plant [4]. On the other hand, environmental factors such as soil characteristics and climate conditions affect mycorrhizal formation and fungal development $[18,30,33]$, and further influence the development of trees or forest ecosystems.

Mongolian pine is an ECM-dependent tree species. It has been previously demonstrated that the trees cannot exist without ectomycorrhizal symbiosis in natural forests $[1,3,11]$. A few studies have reported that the amount and the number of species of mycorrhizal fungi in surface soil of naturally developed Mongolian pine forests were significantly higher than in planted forests on sandy soil [42]. However, little information is available on the effects of mycorrhizal inoculation on the growth of Mongolian pine and the responses of ECM to environmental conditions in sandy soils. In addition, it is not known whether ECM may alleviate the decline of Mongolian pine plantations on sandy soil.

Therefore, the objectives of the present study were, first, to confirm the beneficial effects of major species of ECM on Mongolian pine seedlings; second, to examine the effects of environmental factors such as temperature, soil moisture and $\mathrm{pH}$ on the survival and growth of three major species of ECM obtained from Mongolian pine plantations on sandy soil; and finally, to investigate the effects of environmental factors on survival and growth of ECM species under laboratory conditions to conclude whether an interaction between ECM species and field conditions may influence the decline of Mongolian pine plantations on sandy soils.

\section{MATERIALS AND METHODS}

\subsection{Study site}

The study site was located in Zhanggutai, Zhangwu County, Liaoning Province, China, in the southeastern Keerqin sandlands (N $42^{\circ} 39.7^{\prime}$, E $122^{\circ}$ 33.6', altitude $247.6 \mathrm{~m}$ ) (Fig. 1). The experimental area forms part of a semiarid region. The mean annual air temperature is $5.7^{\circ} \mathrm{C}$, and the minimum and maximum air temperatures (1954-2004) are $-29.5^{\circ} \mathrm{C}$ and $37.2{ }^{\circ} \mathrm{C}$, respectively. Annual precipitation is $450.0 \mathrm{~mm}$ (minimum $224.8 \mathrm{~mm}$ and maximum $661.3 \mathrm{~mm}$, during 1954-2004) and annual evaporation is about $1700.0 \mathrm{~mm}$. The frost-free period is about 154 days [34, 41]. The major soil type is classified into the Semiaripsamment taxonomic group that is developed from sandy parent material through the action of wind $[8,38]$. The current average groundwater table is $5.3 \mathrm{~m} \mathrm{[41].}$

\subsection{Environmental conditions at the study site}

Environmental factors such as soil pH, soil water content, soil potential and surface soil temperature were measured on the 
Table I. Information on the plantation stands (A) and distribution of roots under different plantation ages for Mongolian pine trees in the stands (A, B).

\begin{tabular}{|c|c|c|c|c|c|c|}
\hline \multirow[t]{2}{*}{ Age (year) } & \multirow[t]{2}{*}{ Stem density $\left(\right.$ stem ha $\left.{ }^{-1}\right)$} & \multirow[t]{2}{*}{ Mean $\mathrm{DBH}^{*}(\mathrm{~cm})$} & \multirow[t]{2}{*}{ Mean height (m) } & \multicolumn{3}{|c|}{$\begin{array}{l}\text { Distribution of roots depending on soil layers (ratios of the } \\
\text { weight in different layers to the overall weight, } \% \text { ) }\end{array}$} \\
\hline & & & & $0-20 \mathrm{~cm}$ & $20-40 \mathrm{~cm}$ & $>40 \mathrm{~cm}$ \\
\hline 13 & 2640 & 7.9 & 4.2 & 13.5 & 68.1 & 18.4 \\
\hline 26 & 2115 & 16.9 & 8.8 & 8.4 & 79.5 & 12.1 \\
\hline 26 & 2510 & 15.7 & 9.6 & 5.2 & 81.3 & 13.5 \\
\hline 28 & 2310 & 14.3 & 9.1 & 6.1 & 76.7 & 17.2 \\
\hline$* * 33$ & 2432 & 15.6 & 10.2 & 5.3 & 84.2 & 10.5 \\
\hline 42 & 1025 & 16.8 & 11.6 & 3.2 & 80.4 & 16.4 \\
\hline Mean & 2172 & 14.5 & 8.9 & 7.0 & 78.4 & 14.7 \\
\hline
\end{tabular}

* DBH: diameter at breast height (at $1.3 \mathrm{~m}$ ).

** The roots of the three sample trees in this stand were classified into 3 classes, as shown in Table IB.

B

\begin{tabular}{|c|c|c|c|c|c|c|c|c|}
\hline \multirow{3}{*}{ Soil layer $(\mathrm{cm})$} & \multicolumn{8}{|c|}{ Dry weight of root amount for Pinus sylvestris var. mongolica (kg) (mean of one tree) } \\
\hline & \multicolumn{4}{|c|}{ Absorbing roots } & \multicolumn{2}{|c|}{ Unabsorbing roots } & \multirow[b]{2}{*}{ Total } & \multirow{2}{*}{ Percentage $(\%)$} \\
\hline & $0-1 \mathrm{~mm}$ & Percentage $(\%)$ & $1-5 \mathrm{~mm}$ & Percentage $(\%)$ & $>5 \mathrm{~mm}$ & Percentage $(\%)$ & & \\
\hline $0-20$ & 2.31 & 19.51 & 1.66 & 28.38 & 12.84 & 8,21 & 16.81 & 9.66 \\
\hline $20-40$ & 7.76 & 65.54 & 2.91 & 49.74 & 126.54 & 80.93 & 137.21 & 78.84 \\
\hline$>40$ & 1.77 & 11.95 & 1.28 & 21.88 & 16.97 & 10.85 & 20.02 & 11.50 \\
\hline Total & 11.84 & & 5.85 & & 156.36 & & 174.05 & \\
\hline
\end{tabular}

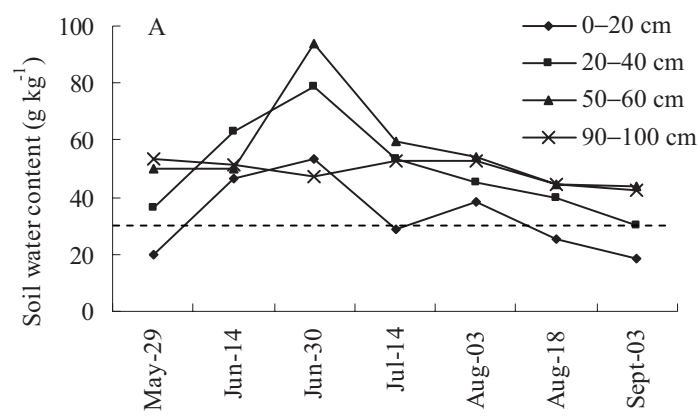

Month-date, 2002

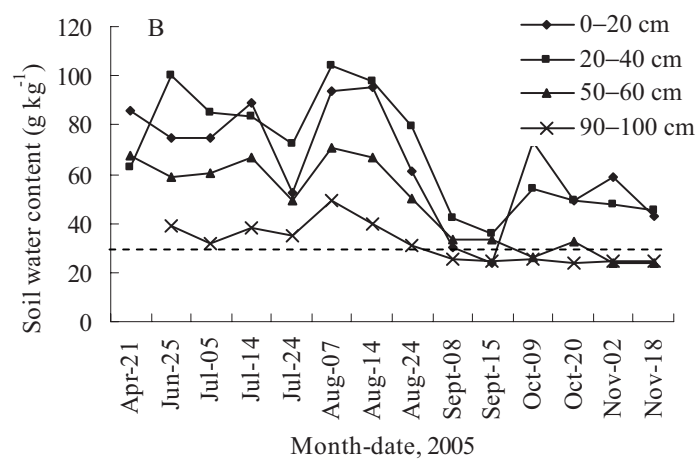

Figure 2. Mean soil water contents at different soil layers in the experimental site on sandy land, A: in 2002; B: in 2005.

experimental site in 13- to 42-year-old Mongolian pine plantation stands. The total area of the stands was 3.65 ha, and detailed information on the stands is given in Table IA.

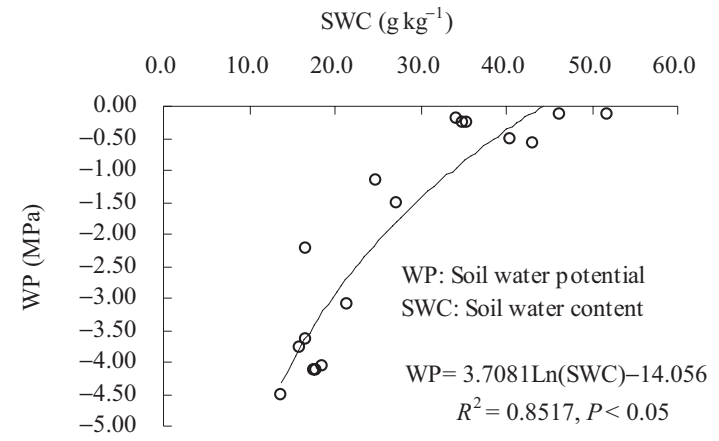

Figure 3. Relationship between soil water content and soil water potential in sandy soil.

Soil $\mathrm{pH}$ was measured in a 1:2.5 mixture of soil and distilled water with a glass electrode, using 12 or 15 random soil samples obtained from the experimental site $[12,13]$.

Soil water content (SWC) was randomly measured in the plantation stands in 2002 and 2005 by time-domain reflectometry (TDR), using an instrument from TRIME-EZ in Germany. SWC was generally sampled twice (at the start or end of the month and in the middle of the month) for each month during the growing season. If it rained on a scheduled sampling date, the sampling would be postponed for at least three days (Fig. 2). Because water potential values were needed to determine the effects of water conditions on growth and survival of ectomycorrhizal fungi (refer to Section 2.4), the relationships between soil water content and potential were established using a Psypro Dew Point microvoltmeter (Wescor, Inc., USA) and soil water content values obtained using TDR in the field (Fig. 3).

Soil temperatures were observed in an open area near the experimental site during 2003 and 2005, using PT100 thermometers 

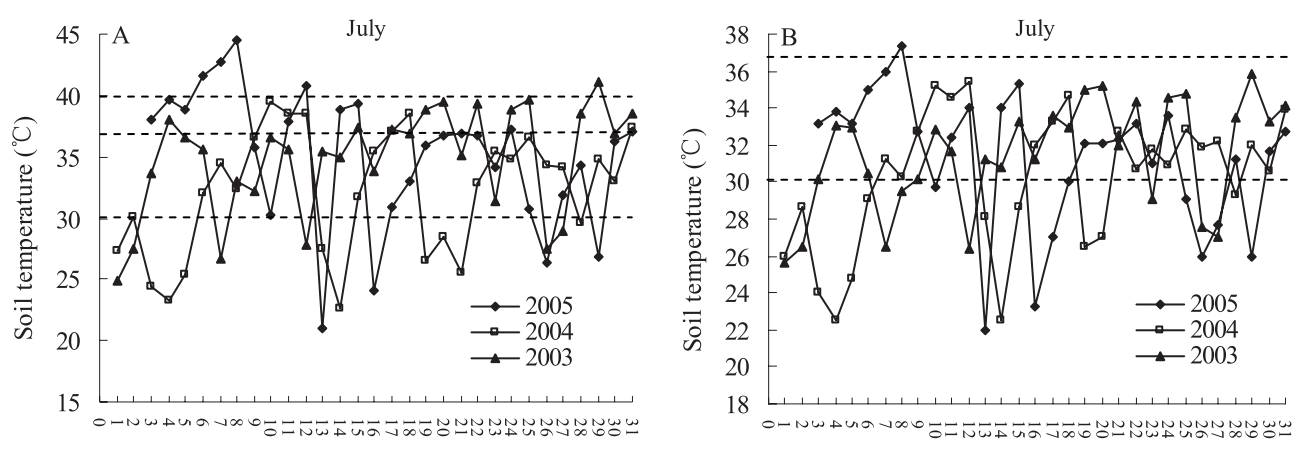

Date (day)

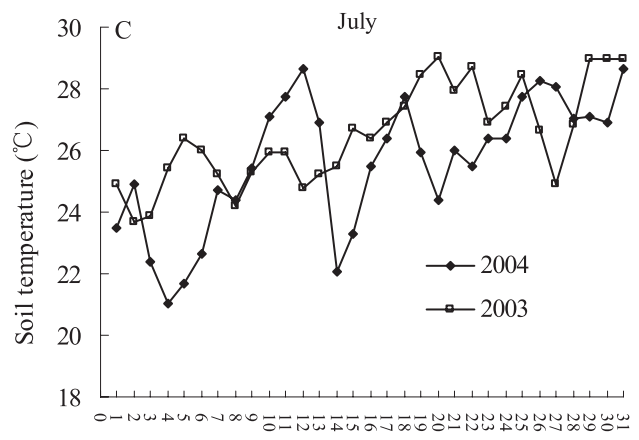

Date (day)

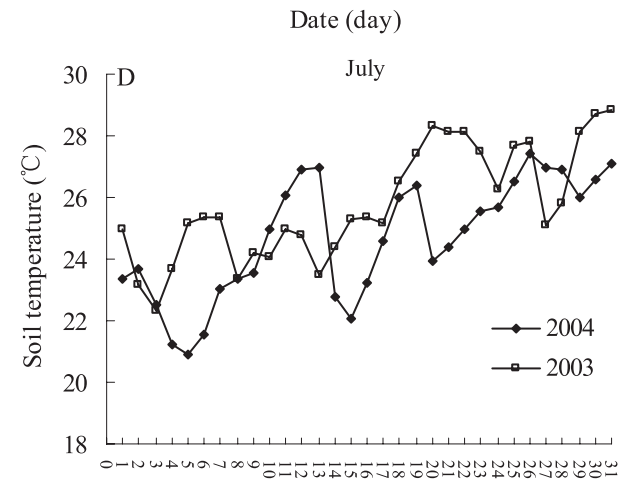

Date (day)

Figure 4. Soil temperature at experimental site: A: at $5 \mathrm{~cm}, \mathrm{~B}$ : at $10 \mathrm{~cm}, \mathrm{C}$ : at $20 \mathrm{~cm}$ and D: at $40 \mathrm{~cm}(2003$, 2004 and 2005). We present the temperature at 14:00 (GMT+008) in July because the annual maximum mean temperature appeared in July, and the daily maximum occurred at 14:00, which are important to the growth and survival of ECM.

produced in Tianjin, China. The thermometers were set up at 5-, 10-, 20- and 40-cm depths in sandy soil to obtain temperature measurements at various depths. Temperatures were recorded every two hours during each day. Figure 4 presents temperature values at 14:00 $(\mathrm{GMT}+8)$ in July because the maximum mean temperature was observed in July [42], a fact which is important for the growth and survival of ECM. The relationship between temperatures outside and inside the plantation stands at $5-\mathrm{cm}$ soil depth was determined by the synchronous observations of temperatures inside and outside the plantation stands in 2006 (Appendix A).

\subsection{Distribution of root systems}

The distribution of ECM corresponds directly with that of roots, especially fine roots $[1,34,35,42]$. Therefore, the root distribution of Mongolian pine trees of different ages in the plantation stands was examined. The roots were measured using the following procedure. Three trees of average diameter and height within an even-age stand were selected as sample trees. A horizontal semicircle centered on the tree and with a radius of $2 \mathrm{~m}$ was defined for collection of roots. Three soil layers were defined: $0-20 \mathrm{~cm}, 20-40 \mathrm{~cm}$ and $40-150 \mathrm{~cm}$ in depth. All roots in the three soil layers within the semicircle were collected. Wet weight and dry weight of the roots were measured (Tab. IA). In addition, the roots of three sample trees within a 33-year-old stand (stem density $=2432$ trees ha ${ }^{-1}$, mean $\mathrm{DBH}=15.6 \mathrm{~cm}$, mean $\mathrm{H}=$ $10.2 \mathrm{~m}$ ) were classified into three classes: less than or equal to $1 \mathrm{~mm}$, between 1 and $5 \mathrm{~mm}$, and more than $5 \mathrm{~mm}$ in diameter for each of the three layers (Tab. IB).
Meanwhile, root development of the natural regeneration seedlings in Mongolian pine plantation stands was investigated at the end of October. The root lengths of the regenerating seedlings were all less than $5 \mathrm{~cm}$, and no seedlings were more than one year old.

\subsection{ECM experiment}

\subsubsection{Collection of ECM}

The ECM present in the Mongolian pine plantation usually produce fruiting bodies from the beginning of July to the end of September. Fruiting bodies were systematically uncovered, collected and identified in the experimental site. Mycelia were obtained from fresh fruiting bodies and isolated in solid potato-dextrose-marmite agar (PDMA) medium $[11,36]$. Three major ECM species were then selected for the experiment according to the work of Zhang et al. [36]: Boletus sp., Lactarius deliciosus and L. sp. All three species have been previously confirmed as symbionts with Mongolian pine [32, 36]. The pure strains thus obtained were cultured in modified MelinNorkrans (MMN) solid medium [22] (two types of MMN were used in this work, one liquid, the other solid). The cultured ECM fungi were used in the following experiments.

\subsubsection{Pot experiment}

The soil substrate for the pot experiment was taken from the 0 $20 \mathrm{~cm}$ soil layer in the experimental plantation site. The physical and 
Table II. Physical and chemical characteristies of the sandy soil for the pot experiment in the field.

\begin{tabular}{|c|c|c|c|c|c|c|c|c|c|c|c|c|}
\hline \multirow{2}{*}{$\begin{array}{l}\text { Total } \\
\text { nitrogen } \\
\left(\mathrm{mg} \mathrm{g}^{-1}\right)\end{array}$} & \multirow{2}{*}{$\begin{array}{c}\text { Available } \\
\text { nitrogen } \\
\left(\mathrm{mg} \mathrm{g}^{-1}\right)\end{array}$} & \multirow{2}{*}{$\begin{array}{c}\text { Available } \\
\text { potassium } \\
\left(\mathrm{mg} \mathrm{g}^{-1}\right)\end{array}$} & \multirow{2}{*}{$\begin{array}{c}\text { Available } \\
\text { phosphorus } \\
\left(\mathrm{mg} \mathrm{g}^{-1}\right)\end{array}$} & \multirow{2}{*}{$\begin{array}{c}\text { Organic } \\
\text { matter } \\
\left(\mathrm{mg} \mathrm{g}^{-1}\right)\end{array}$} & \multirow[t]{2}{*}{$\mathrm{pH}$} & \multirow{2}{*}{$\begin{array}{l}\mathrm{C}: \mathrm{N} \\
\text { ratio }\end{array}$} & \multicolumn{6}{|c|}{ Texture $(\%)$ and sand classes $(\mathrm{mm}) *$} \\
\hline & & & & & & & $<0.001$ & $0.001-0.005$ & $0.005-0.01$ & $0.01-0.05$ & $0.05-0.25$ & $0.25-1.0$ \\
\hline 0.4401 & 0.0335 & 0.0238 & 0.0510 & 5.26 & 6.35 & 6.92 & 7.56 & 2.43 & 0.85 & 11.55 & 50.68 & 26.93 \\
\hline
\end{tabular}

* Following [14] (1989).

chemical characteristics of the selected soil are described in Table II. The soil was sterilized using a steam sterilizer (YX-280B, Jiangjin, China) at $120{ }^{\circ} \mathrm{C}$ for $2 \mathrm{~h}$ before the start of the pot experiment. To avoid solar overheating, double-walled porcelain clay pots were used. Pots were filled with $7.5 \mathrm{~kg}$ soil (air-dry weight). Seeds of Mongolian pine were collected from the plantation stands and sterilized with $10 \%$ hydrogen peroxide for $15 \mathrm{~min}$ [42]. Then the sterilized seeds were sown in the pots (50 seeds per pot) in November 2003. After five months of seed germination, ten average-sized seedlings per pot were selected for inoculation with the ECM strains (April 2004). The experimental design contained four replicates of four treatments: the control without inoculation $(\mathrm{CK})$, and three treatments with one or two ECM strains ( $B$. sp. separately, $L$. sp.separately, and the combination of $B$. sp. and $L$. sp.), with complete randomization. The experimental pots were set up in a movable greenhouse at the plantation site. Inoculations were performed by putting the liquid mycelia into the pot soil around the seedlings $(1: 20 ; \mathrm{v}: \mathrm{v})$ using the method described by $\mathrm{Xu}$ et al. (2004) [35]. During the whole growing period, the soil water content was kept at $55 \%$ of the water-holding capacity of the soil in the pot.

Six months after inoculation (October 2004), the number and lengths of roots and shoots were determined. The dry weight of the roots and shoots was estimated after drying the samples for one week at $65{ }^{\circ} \mathrm{C}$ [2]. All seedlings were examined for the presence or absence of ECM infection and for ECM density in the fine root tips for each treatment (number of ECM short roots/total number of short roots $\times 100 \%)$. The processes were carried out as described by $\mathrm{Xu}$ et al. (2004) [35] and Duponnois et al. (2005) [7].

\subsubsection{Culture of ECM under different conditions}

$$
-\mathrm{pH}
$$

Isolates of B. sp., L. deliciosus and L.sp. were cultured in both solid and liquid MMN. Uniform inoculum plugs $(8 \mathrm{~mm}$ in diameter) were taken from the colony edge and subcultured in Petri dishes with solid MMN. Plugs of the same diameter were put into the liquid MMN. To maintain the $\mathrm{pH}$ values, a 1:1 (v:v) mixture of concentrated $\mathrm{H}_{2} \mathrm{SO}_{4}$ and $\mathrm{HNO}_{3}$ was used to control the $\mathrm{pH}$ range of the MMN in experiments at $\mathrm{pH} 4,5$ and 6. However, $\mathrm{NaOH}$ was used to control $\mathrm{pH}$ values in experiments at $\mathrm{pH} 7,8$ and 9 using the method described by Sanchez et al. [28]. According to Hung and Trappe's (1983) suggestions [13], buffers were not used for $\mathrm{pH}$ adjustment, because some of them, such as phosphate or polycarboxylic buffers, may alter some of the components of the medium [10, 13]. Most ECM respond to increasing mineral $\mathrm{N}$ with varying intensities of growth, and nitrogen deposition may enrich the $\mathrm{N}$ abundance of the soil [14]. The authors therefore observed the effects of these acid components on the in-vitro growth of the three ECM strains. Inoculated plates were incubated in the dark at $25{ }^{\circ} \mathrm{C}$ for 15 days. On the solid $\mathrm{MMN}$, colony diameters along a given orientation were measured.
A minimum of three replicates was obtained for each treatment. The mycelial biomass was obtained by filtering the liquid MMN, and then oven-drying was conducted at $105{ }^{\circ} \mathrm{C}$ until the oven-dry weight remained constant. Growth observations were averaged for the three ECM strains in the MMN with $\mathrm{pH}$ values of 4,5 and 6 controlled by various acids.

- Water stress (induced by polyethylene glycol (PEG))

Isolates of mycelial plugs were subcultured in Petri dishes containing liquid MMN with different water potentials induced using polyethylene glycol (PEG-6000) [23]. Twenty-five milliliters MMN were dissolved in PEG-6000 to reach the following PEG concentrations: $10 \%$ (100 $\left.\mathrm{g} \mathrm{L}^{-1}\right), 20 \%\left(200 \mathrm{~g} \mathrm{~L}^{-1}\right), 25 \%\left(250 \mathrm{~g} \mathrm{~L}^{-1}\right)$ and $30 \%$ (300 $\mathrm{g} \mathrm{L}^{-1}$ ) of PEG (weight ratios), which produced water potentials of $-0.20,-0.75,-1.35$ and $-1.53 \mathrm{Mpa}$, respectively [23, 28, 29]. The water potential values were verified using a Psypro Dew Point microvoltmeter (Wescor, Inc., USA). A control (no PEG stress, CK) was observed together with the drought-stressed samples. A sterilized grit support was placed in the Petri dishes with the liquid medium just covering the grit, and a fiber filter was placed on the grit with an inoculation on the filter. Each Petri dish contained $25 \mathrm{~mL} \mathrm{MMN} \mathrm{for} \mathrm{a}$ minimum of three replicates for each treatment [28]. To determine whether PEG-6000 was a suitable carbon source in the experiment, the three strains were grown on liquid MMN with different carbon sources substituted for glucose. According to Zhu et al. (2005) [42], it is difficult to remove PEG from fungal tissues, which gives rise to unrepresentative dry weight values. Therefore, dry weight was not used as a mycelial growth index in this work, but rather colony diameter. The cultures were incubated at $25^{\circ} \mathrm{C}$ for 15 days. The colony diameter was measured at the end of the experiment.

- Temperature

The cultures of the three ECM strains were conducted in solid MMN with uniform inoculum plugs ( $8 \mathrm{~mm}$ in diameter). The ECM fungi were incubated in the dark at $5,10,20,25,28,30,37$ and $40{ }^{\circ} \mathrm{C}$. A minimum of three replicates was obtained for each treatment. After 15 days of incubation, colony diameters for each treatment were measured.

\subsection{Statistical analyses}

The mean values of each experimental factor were calculated from the observations at each time. Data for percentages of ECM colonization, seedling growth parameters and ECM culture responses were analyzed using analysis of variance (one-way ANOVA), applying when necessary a prior $(\log n+1)$ transformation to obtain normality [2]. To compare mean values, Duncan's multiple-range test $(P<0.05)$ was used. Correlation coefficients were determined to quantify relationships between seedling mycorrhizal colonization and growth parameters $(P<0.05)$. All statistical analyses were carried out using the SPSS statistical software package, version 13.0. 


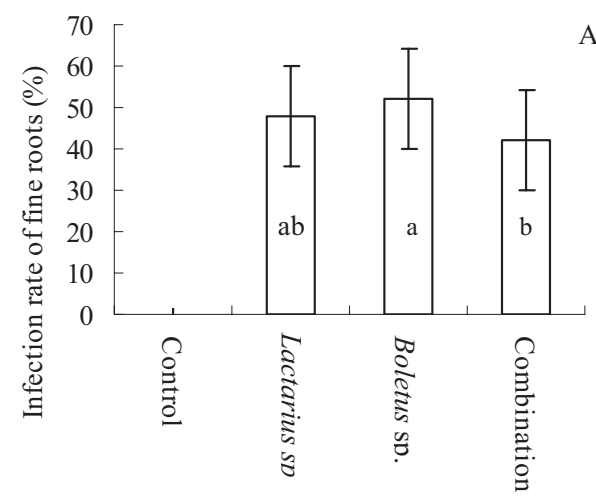

Inoculation treatment

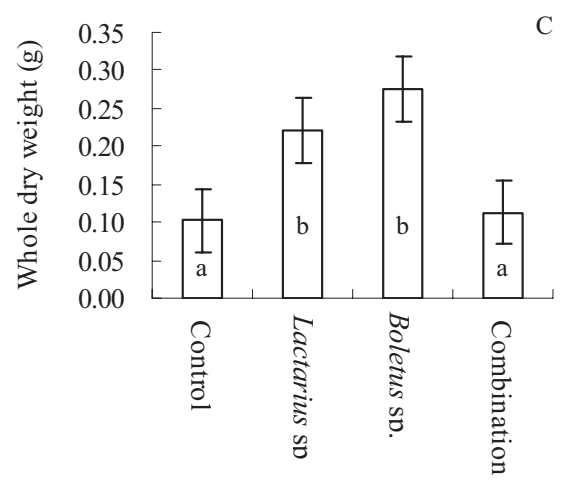

Inoculation treatment

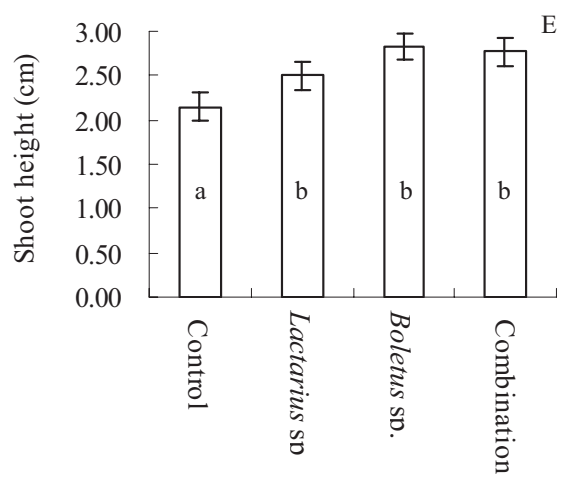

Inoculation treatment

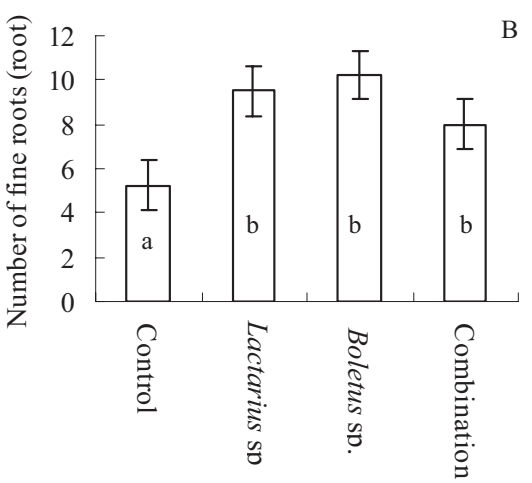

Inoculation treatment

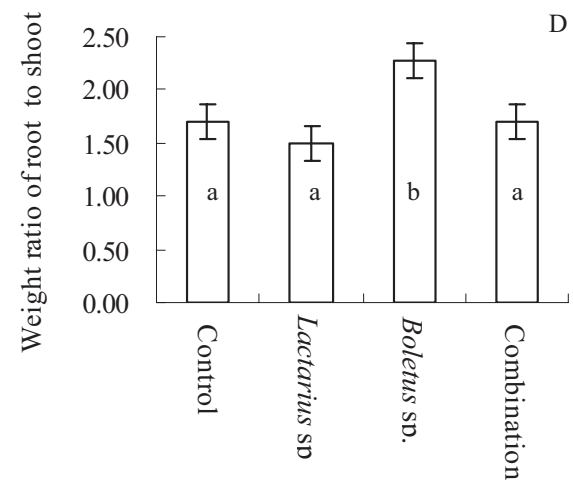

Inoculation treatment

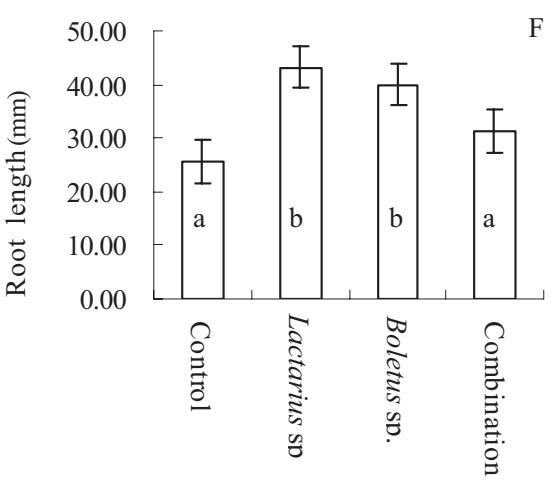

Inoculation treatment

Figure 5. Growth parameters of Mongolian pine seedlings. A: Infection rate of fine roots, B: number of fine roots, C: whole weight, D: shoot height, E: weight ratio of root to shoot and F: root length. The vertical bar indicates the standard deviation; different letters indicate the significant effect of inoculation on the growth parameters at $P<0.05$.

\section{RESULTS}

\subsection{Effects of ECM inoculation on seedling growth in the pot experiment}

Values obtained for number of fine roots, combined weight of roots, root/shoot weight ratio, root length and shoot height are shown in Figure 5. After the first growing season in the greenhouse established at the plantation site, about $47 \%$ of the fine roots of the inoculated seedlings were colonized with ECM, as compared with no colonization for the control seedlings (Fig. 5A). The number of fine roots, shoot height of the inoculated seedlings and the combined dry root weight and root length of pure-species inoculated seedlings (by $B$. sp. separately and $L$.sp. separately) were significantly higher than the corresponding values for the control treatment $(P<0.05)$ (Figs. 5B and 5E) and for the combination inoculation treatments (by mixed B. sp. and L. sp.) (Figs. 5C and 5F). The number of inoculated roots, shoot height, root length and combined dry weight of roots were significantly correlated with the percentage of ECM colonization $(r=0.983, r=0.881$, $r=0.847$ and $r=0.820$, respectively). However, there was no significant correlation between root/shoot weight ratio and the percentage of ECM colonization (Fig. 5D). 

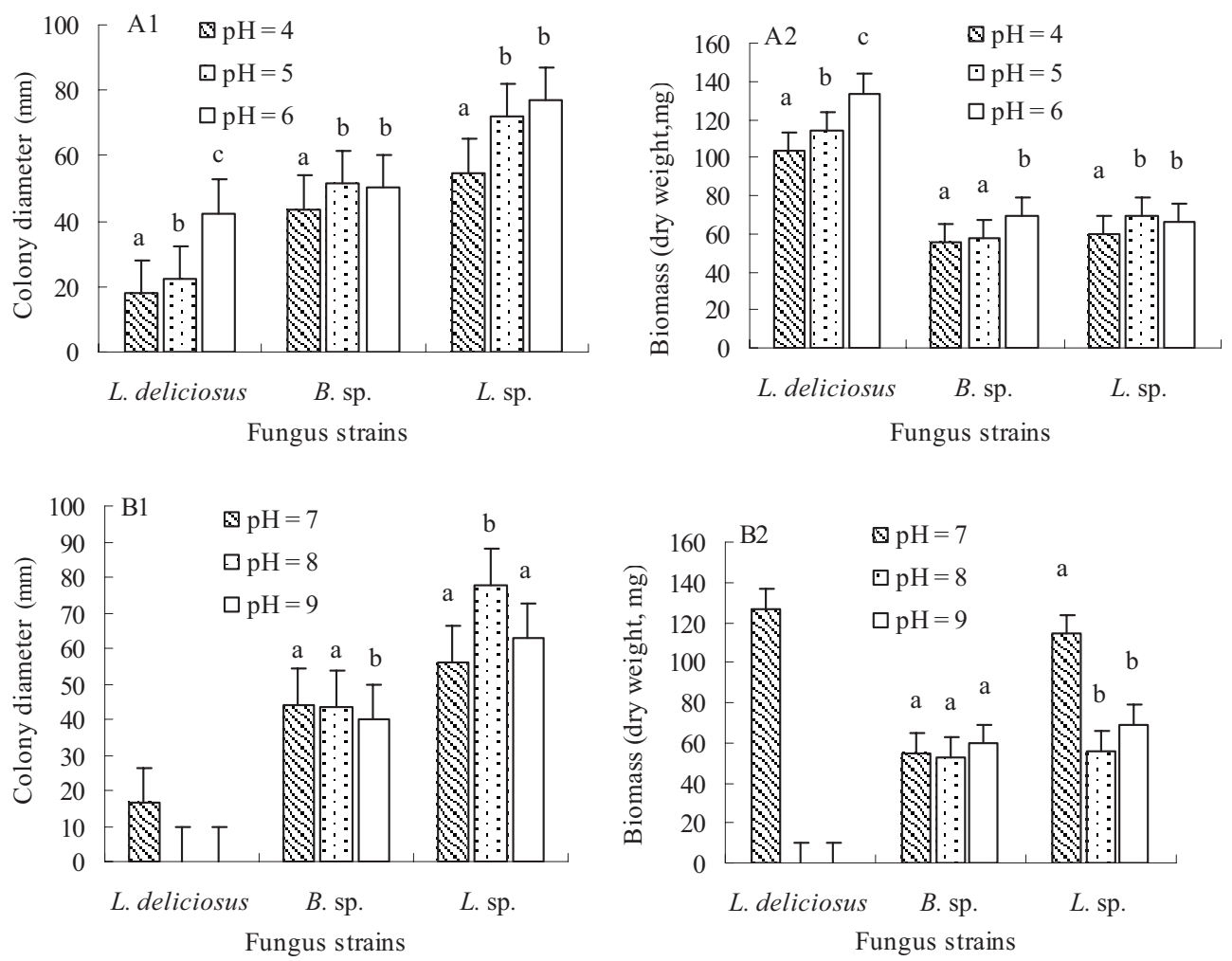

Figure 6. Colony diameters $(\mathrm{mm})$ and dry weights $(\mathrm{mg})$ of the different ECM strains at various pH values. A: The media modified with $\mathrm{H} 2 \mathrm{SO} 4$, HNO3, H2SO4,+ HNO3 ( $\mathrm{pH}=4,5,6)$; B: The media modified with $\mathrm{NaOH}(\mathrm{pH}=7,8,9)$; 1: Colony diameters (mm); 2: dry weights (mg); Different letters indicate the significant differences among various $\mathrm{pH}$ values at $P<0.05$.

\subsection{Effects of $\mathbf{p H}$, drought stress and temperature on ECM culture}

\subsection{1. $p H$}

Of the three ECM strains, L. deliciosus and B.sp. showed minor differences in diameter increase and biomass growth in both acid and alkaline media. However, there was a trend towards improved growth as $\mathrm{pH}$ increased from 4 to 6 , and then a decline as $\mathrm{pH}$ increased from 7 to 9 (Fig. 6). In the case of $L$. sp, growth was constant over the entire $\mathrm{pH}$ range of 4-9 (Fig. 6). On the MNN acid media, all three ECM strains had the lowest colony diameter at $\mathrm{pH}=4$. The maximum growth as measured by colony diameter was observed at $\mathrm{pH}=6$ for $L$. deliciosus and $L$. sp., while for B.sp., the difference between colony diameter at $\mathrm{pH}=5$ and $\mathrm{pH}=6$ was not significant (Fig. 6A1). On the MNN media controlled by $\mathrm{NaOH}$, the maximum growth as measured by both colony diameter and biomass was observed at $\mathrm{pH}=7$ for L. deliciosus. In the case of both $B$. sp. and $L$. sp., only slight differences were observed among these three $\mathrm{pH}$ values $(\mathrm{pH}=7,8$ and 9). For $B$. sp., maximum growth occurred at $\mathrm{pH}=7$ as measured by colony diameter and at $\mathrm{pH}=9$ as measured by biomass. For L. sp., maximum growth was observed at $\mathrm{pH}=7$ as measured by colony diameter and at $\mathrm{pH}=8$ as measured by biomass (Fig. 6B).
The optimum $\mathrm{pH}$ values for growth according to colony diameter for the three ECM strains were: for L. deliciosus, 6; for $B$. sp., 5-6; and for $L$. sp., 4-9. When growth was measured by biomass, the optimum $\mathrm{pH}$ values of the three ECM strains were: for $L$. deliciosus, 4-7, and for both $B$. sp. and $L$. sp., 4 9. $B$. sp. and $L$. sp. exhibited a pronounced adaptability to $\mathrm{pH}$ variations (Fig. 6).

\subsubsection{Drought stress (induced by PEG)}

Under the most severe drought stress (30\% PEG, -1.53 $\mathrm{MPa}$ ), none of the three ECM strains (isolates) could grow (Fig. 7). With less drought stress (10\% PEG, $-0.20 \mathrm{MPa}$ ), colony diameter growth of the three ECM strains was improved, but no significant increase was observed compared with the control (Fig. 7). However, under the more severe drought stresses, represented by PEG concentrations of $20 \%$ and $25 \%(-0.75 \mathrm{MPa}$ and $-1.35 \mathrm{Mpa}$, respectively), colony diameters were significantly decreased for the three ECM species (except for $L$. sp.) compared with the control samples (Fig. 7C). There was no change in colony diameter for all three ECM strains with PEG-6000 as a carbon source in the substrate. 

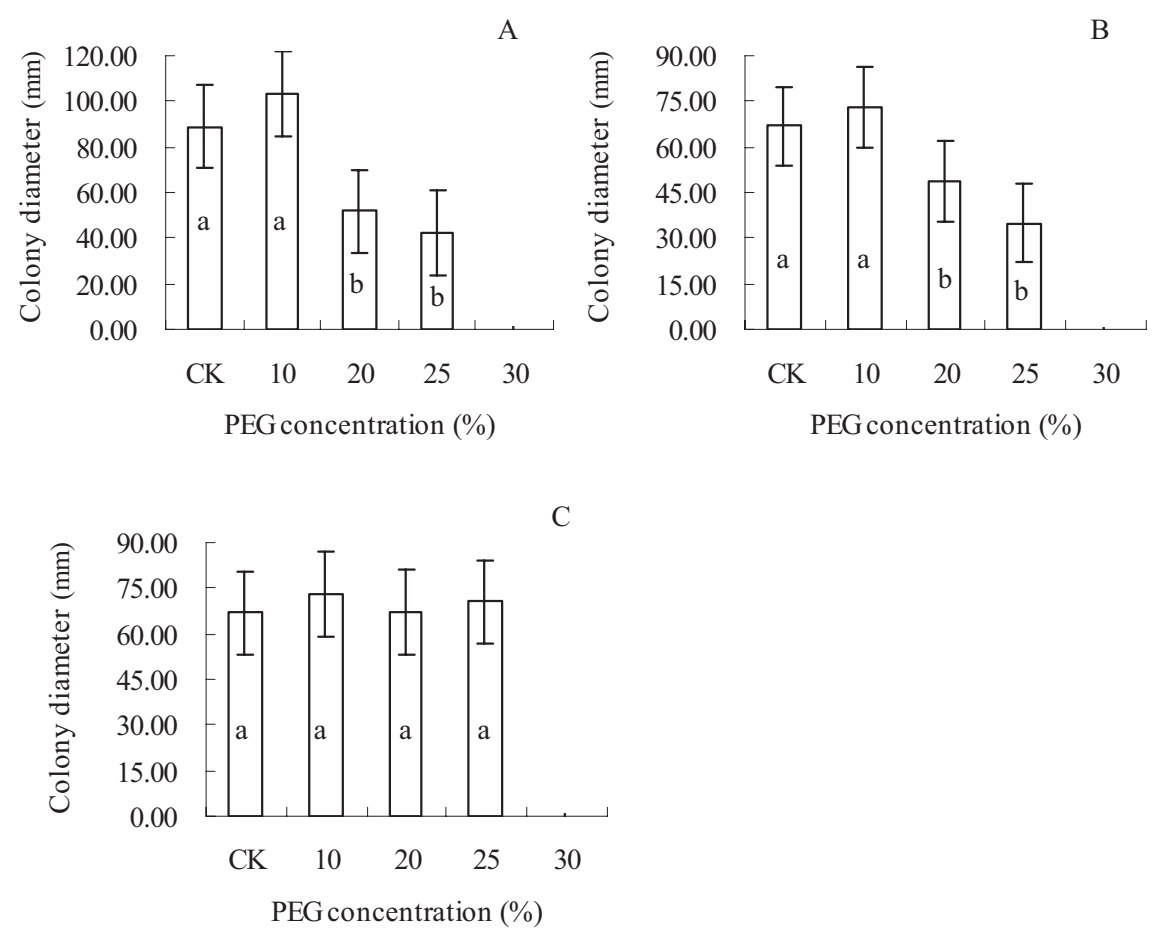

Figure 7. Colony diameter of ECM strains in response to various PEG concentrations. A: L. deliciosus, B: B. sp., C: L. sp. The vertical bar indicates the standard deviation. Different letters indicate the significant effect of PEG concentrations on the growth of ECM strains at $P<0.05$.

\subsubsection{Temperature}

Effect of temperature on ECM growth varied significantly among the three strains. Optimum temperatures for growth of the three ECM strains were found to be $28{ }^{\circ} \mathrm{C}, 25{ }^{\circ} \mathrm{C}-28{ }^{\circ} \mathrm{C}$ and $25{ }^{\circ} \mathrm{C}-30{ }^{\circ} \mathrm{C}$ for $L$. deliciosus, B. sp., and $L$. sp., respectively (Fig. 8). However, among the three ECM strains, $L$. sp. exhibited the fastest mean growth and $L$. deliciosus the slowest mean growth (Figs. 8A and 8C). All the isolates had significantly smaller colony diameters at $20^{\circ} \mathrm{C}$ than those obtained at $25^{\circ} \mathrm{C}$ and $28{ }^{\circ} \mathrm{C}(P<0.05)$. However, at a temperature of $37^{\circ} \mathrm{C}, B$. sp. showed growth efficiency, while L. deliciosus strains exhibited no colony diameter growth at this temperature. At $5{ }^{\circ} \mathrm{C}$ and $40^{\circ} \mathrm{C}$, all isolates showed no development. Therefore, the three strains that could not grow at temperatures of $5{ }^{\circ} \mathrm{C}, 37^{\circ} \mathrm{C}$ or $40{ }^{\circ} \mathrm{C}$ were cultured again under more favorable temperature conditions $\left(25^{\circ} \mathrm{C}-28{ }^{\circ} \mathrm{C}\right)$. The results indicated that the ECM strains which could not grow at the temperature extremes $\left(5{ }^{\circ} \mathrm{C}, 37{ }^{\circ} \mathrm{C}\right.$ or $\left.40{ }^{\circ} \mathrm{C}\right)$ were not similar in their response. Isolates which did not grow at $5{ }^{\circ} \mathrm{C}$ could grow well once the culture temperature condition was suitable, while the isolates which did not grow at $40^{\circ} \mathrm{C}$ or $37^{\circ} \mathrm{C}\left(37^{\circ} \mathrm{C}\right.$ for $L$. deliciosus and $40^{\circ} \mathrm{C}$ for $L$. sp. and $B$. sp.) never grew again, even when the temperature conditions were in their optimum ranges.

\section{DISCUSSION}

The inoculations by $B$. sp., $L$. sp. and the combination of $B$. sp. and $L$. sp. led to a significant increase in ECM colonization and significantly improved the number of fine roots and the shoot lengths of Mongolian pine seedlings in the first growing season (Fig. 5) $(P<0.05)$. A high degree of correlation (greater than 0.80) between growth parameters and colonization rate was also found in the inoculation experiments. These results suggest that ECM inoculation could be used successfully to increase ECM colonization and to improve the growth rates of Mongolian pine seedlings on sterilized sandy soils. In addition, they imply that ECM fungi play a major role in the growth and development of Mongolian pine seedlings or trees in plantations. As for root length and combined dry root weight, results for the seedlings inoculated with a combination of $B$. sp. and $L$. sp. were not significantly different from the control. This observation may be due to an interaction between different ECM strains which delays the effects of inoculation $[2,9,26]$.

One problem with field ECM colonization is that strong environmental or climatic influences, for example, high temperature during drought periods in summer, can reduce or stop ECM colonization, resulting in loss of the inoculation effects $[2,6,24,25]$. The results of this work show that ECM colony diameter growth and biomass production in pure culture are greatly influenced by changes in the $\mathrm{pH}$ of the medium. Sanchez et al. (2001) [28] reported that growth responses to varying levels of acidity differ markedly among species. The three ECM strains used in these experiments could grow at $\mathrm{pH}=4-9$ except for $L$. deliciosus, which could not grow when pH was greater than 8 (Fig. 6B). In particular, B. sp. and $L$. sp. showed vigorous growth at all the $\mathrm{pH}$ levels used in this experiment, exhibiting only a few differences in colony diameter 

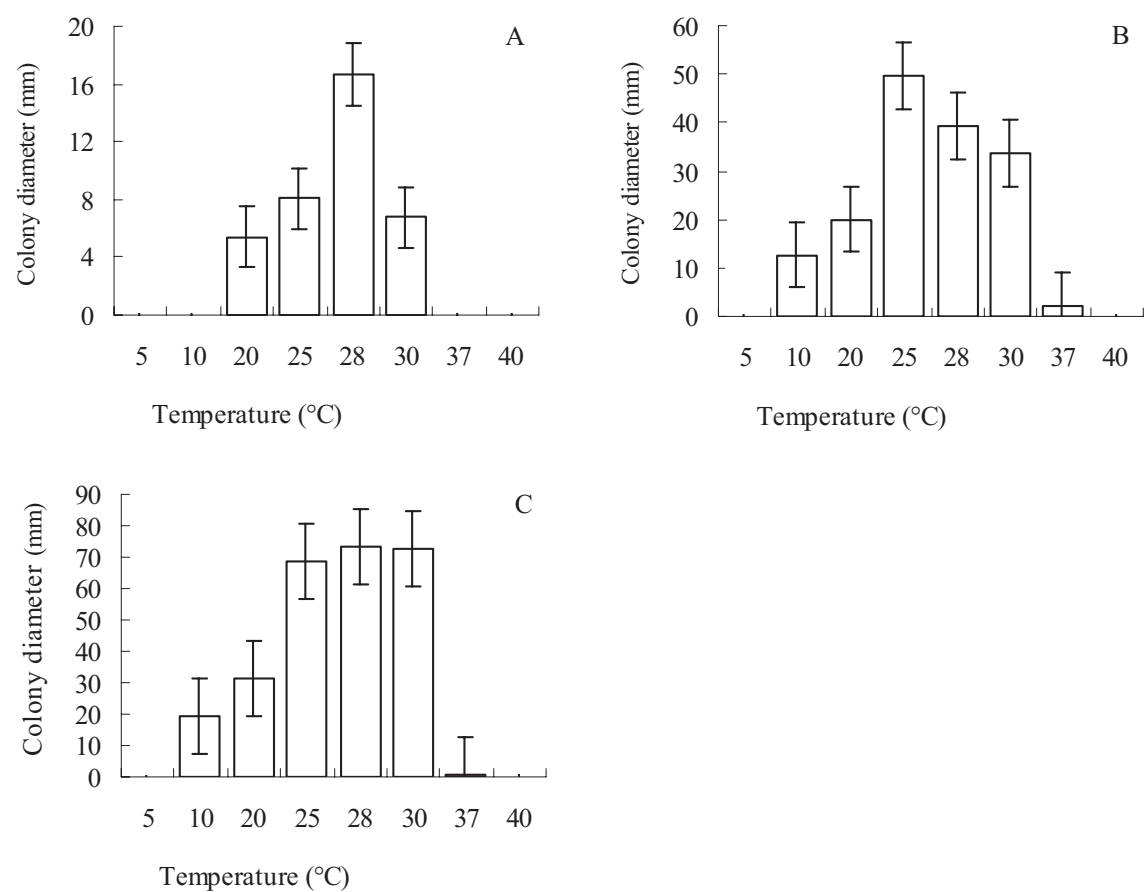

Figure 8. Diameter growth response of ECM to different temperatures. A: L. deliciosus, B: B. sp., C: L. sp. The vertical bar indicates the standard deviation.

and dry weight from one $\mathrm{pH}$ value to another. The optimum $\mathrm{pH}$ values for the growth of $L$. deliciosus and $B$. $\mathrm{sp}$. were in the 57 range, which is in agreement with the conclusion drawn by Han et al. (1993) [10] that these ECM favor acidic conditions. However, it was also found here that $L$. sp. isolates were able to tolerate an alkaline medium ( $\mathrm{pH}=9)$; this result might need further testing because it was not consistent with the conclusion reported by Zhang et al. (1992) [36]. According to the results obtained from the laboratory analysis of the soil in the Mongolian pine plantations (Tab. II, $\mathrm{pH}=6.35 \pm 0.16$ ), it appears that soil $\mathrm{pH}$ should not limit the growth of the tested ECM strains in the Mongolian pine plantations.

The growth response of ECM isolates to drought stresses exhibited two patterns in this study; in the first pattern, ECM growth increased up to a certain stress level (e.g., 10\% PEG stress), beyond which growth decreased (L. deliciosus and $B$. sp., Figs. 7A and 7B). Many ECM strains exhibit a similar pattern, as reported by Zhao et al. (1989) [39]. The second pattern, exhibited for instance by $L$. sp., showed almost no sign of limitation below a certain stress level (e.g., below 30\% PEG stress) (Fig. 7C). The three ECM strains tested here could not survive when PEG concentration was at $30 \%(-1.53 \mathrm{MPa})$. This result was different from the conclusion for the same ECM species, B. sp., as reported by Zhao et al. (1989) [39] that it could grow at $-2.0 \mathrm{MPa}$ drought stress. This may be explained by the conclusion reached by Machado and Braganca [21] that in vitro response to different water potentials may vary even among strains of the same species. It is also worth considering that the origin or provenance of the ECM strains might affect their ability to adapt in vitro to the adverse water potentials. From the observations of soil water content in the Mongolian pine plantations [43], the surface soil water content $(0-20 \mathrm{~cm})$ decreased below $29 \mathrm{~g} \mathrm{~kg}^{-1}$ at some time during the growing season (Fig. 2), meaning that the soil water potential was below $-1.61 \mathrm{MPa}(<-1.53 \mathrm{MPa})$ according to Fig. 3. The three ECM strains tested here could not grow at all under such soil water conditions. In fact, the growth of the three tested ECM strains decreased when the water potential became less than $-0.75 \mathrm{MPa}$, corresponding to a soil water content of less than $36.5 \mathrm{~g} \mathrm{~kg}^{-1}$. Therefore, the ECM at the plantation site in the first $20 \mathrm{~cm}$ of soil depth could well experience stressful water conditions for ECM growth for some months every summer. It was not clear, however, whether or not the ECM strains tested in this experiment by heavy drought stress $(-1.53 \mathrm{MPa})$ could survive and start growing again after the stress was removed, because the stressed ECM were not recultured under appropriate water conditions.

Even a small decrease or increase in temperature can influence ECM growth $[1,10,42]$. No isolates showed any growth or development at $5{ }^{\circ} \mathrm{C}$ in these experiments, but they could start to grow again once the culture temperature conditions were suitable. However, extreme high temperatures caused ECM death; for instance, once the temperature reached $37^{\circ} \mathrm{C}$, L. deliciosus could never grow again (Fig. 8A). The same situation was observed for the other two strains ( $L$. sp. and $B$. sp.) when the temperature reached $40{ }^{\circ} \mathrm{C}$. This matched the observed temperature conditions in some cases in the Mongolian pine plantations on sandy land. For example, soil temperatures at 5- and 10-cm depths in open ground near the plantation site exhibited maximum temperature values up to $44.6{ }^{\circ} \mathrm{C}$ and $37.3{ }^{\circ} \mathrm{C}$, respectively, in July (Figs. $4 \mathrm{~A}$ and $4 \mathrm{~B}$ ), and it was estimated that soil temperatures within the stands would be 
$39.2{ }^{\circ} \mathrm{C}$ at 5 -cm depth (See Appendix A). Such high temperatures would cause the death of some of the tested ECM strains in the upper $5 \mathrm{~cm}$ of soil and prevent the growth of the tested ECM strains within the upper $10 \mathrm{~cm}$ of soil. However, roots of the regenerating seedlings develop within the uppermost $5 \mathrm{~cm}$ of soil (see Section 2.3). Therefore, the regenerating seedlings would not form the effective ECM roots at all, and further disappear within one growing season. In addition, the severe lack of moisture stressed the photosynthesis of regenerating seedlings; according to the reported results of effects of severe moisture stresses on physiological properties of Pinus sylvestris var. mongolica seedlings (photosynthesis was severely stressed under $30 \%$ and $20 \%$ field capacity of water, about $50 \mathrm{~g} \mathrm{~kg}^{-1}$ ) $[6,19,42]$.

Another problem related to the effects of environmental factors on the survival and growth of ECM strains in the Mongolian pine plantations is the distribution of tree root systems, because the distribution of ECM is directly related to that of roots, especially of fine roots $[1,34,35,42]$. Therefore, the root distribution of Mongolian pine was investigated in the present study. The results indicated that about $80 \%$ of the roots were found in the $20-40 \mathrm{~cm}$ soil layer, and more than $85 \%$ were found between the surface and a depth of $40 \mathrm{~cm}$ (Tab. IA). Furthermore, about $65 \%$ of the roots less than $1 \mathrm{~mm}$ in diameter, and $50 \%$ of the roots between $1 \mathrm{~mm}$ and $5 \mathrm{~mm}$ in diameter, were found at a depth between 20 and $40 \mathrm{~cm}$ (Tab. IB). Combining the observations of soil water content (soil water potential) in the plantation site, it was clear that the water conditions within the 20-40-cm deep soil layer were substantially better than in shallower layers (Fig. 2). In addition, the temperature in the month of July (the highest mean temperature of the year) within the 20-40-cm deep soil layer fell just within the optimum range for the growth of the major ECM strains (Figs. 4C and 4D). These results suggest that the soil water conditions and temperature in the root layer, especially for the fine roots, were suitable for the growth of the tested ECM strains in the plantations.

\section{CONCLUSIONS}

The beneficial effects of ECM on the growth of Mongolian pine seedlings were confirmed by the response to inoculation in the six-month pot experiment. Furthermore, the effects of soil $\mathrm{pH}$, drought stress and temperature on the growth and survival of the three ECM strains indicated that soil $\mathrm{pH}$ was not the main factor influencing the growth of the tested ECM strains; however, extreme high temperatures and drought stress had significant effects on the adaptability of the three ECM strains. The three ECM strains failed to grow under severe drought stress $(-1.53 \mathrm{MPa})$ and extreme temperatures (below $5{ }^{\circ} \mathrm{C}$ and over $37^{\circ} \mathrm{C}$ or $40{ }^{\circ} \mathrm{C}$ ); in particular, high temperatures in excess of $37^{\circ} \mathrm{C}$ or $40^{\circ} \mathrm{C}$ were fatal to the tested ECM strains. Moreover, severe drought stress and extreme high temperatures influence soil water conditions within the uppermost 5 or $10 \mathrm{~cm}$ of soil in the sandy land plantation site. The ECM strains tested would therefore not grow or survive within the uppermost 5 or $10 \mathrm{~cm}$ of soil under the observed field site con- ditions. However, the soil water conditions and temperatures were not extreme in the 20-40-cm deep soil layer, but were suitable for growth of the tested ECM strains. Therefore, the conclusion could be drawn that the failure of natural regeneration in Mongolian pine plantations might be caused by the lack of ECM colonization of the roots of regenerating seedlings developing within the uppermost $5 \mathrm{~cm}$ of soil. The decline of Mongolian pine plantations characterized by shoot dieback, low growth rate and tree death might be alleviated by the better conditions for ECM development within the 20-40 cm soil layer, in which about $65 \%$ of the fine roots (less than $1 \mathrm{~mm}$ in diameter) of Mongolian pine trees are distributed. Further research is required to explain wider aspects of reported declines in growth and failures of natural regeneration.

Acknowledgements: We would like to thank Drs. Xu Hui, Zhang Huiwen and Ms. Han Guiyun for their valuable discussion and suggestions during the experiment. We would like to acknowledge the anonymous referees and the editors for their valuable criticisms and detailed revisions of this manuscript. Dr. Singh Anand Narain from Panjab University, India, checked the manuscript carefully. International Science Editing Compuscript Ltd. (www.internationalscienceediting.com) did the English editing. The research was supported by the 100-young-researcher-project of the Chinese Academy of Sciences, National Natural Science Foundation (30671669), and by the innovation research project of the Chinese Academy of Sciences (KZCX3-SW-418, SCX2-YW-N-031-1).

\section{REFERENCES}

[1] Allen M.F., 1991. The Ecology of Mycorrhizae, Cambridge, Cambridge University Press.

[2] Baum C., Stetter U., Makeschin F., 2002. Growth response of Populus trichocarpa to inoculation by the ectomycorrhizal fungus Laccaria laccata in a pot and a field experiment, For. Ecol. Manage. 163: $1-8$

[3] Bi G.C., Guo X.Z., Zang M., 1989. Influence of temperature on colony growth of ectomycorrhizal fungi in pure culture, For. Res. 247-253 (in Chinese).

[4] Brundrett M., Malajczuk N., Gong M.Q., Xu D.Q., Snelling S., Dell B., 2005. Nursery inoculation of Eucalyptus seedlings in Western Australia and Southern China using spores and mycelial inoculum of diverse ectomycorrhizal fungi from different climatic regions, For. Ecol. Manage. 209: 193-205.

[5] Chang X.L., Zhao W.Z., 1990. Study on moisture physiology of Pinus sylvestris var. mongolica and Populus simonii and water condition of woodland, Chin. J. Desert. 10: 18-24 (in Chinese with English abstract).

[6] Chambel M.R., Climent J., Alía R., 2007. Divergence among species and populations of Mediterranean pines in biomass allocation of seedlings grown under two watering regimes, Ann. For. Sci. 64: 87-97.

[7] Duponnois R., Founouneb H., Masseb D., Pontanierc R., 2005. Inoculation of Acacia holosericea with ectomycorrhizal fungi in a semiarid site in Senegal: growth response and influences on the mycorrhizal soil infectivity after 2 years plantation, For. Ecol. Manage. 207: 351-362.

[8] Fisher R. F., Binkley D., 2000. Ecology and Management of Forest Soils. John Wiley \& Sons (Asia) Pte. Ltd., 3rd ed. 
[9] Garbaye J., Churin J.L., 1997. Growth stimulation of young oak plantations inoculated with the ectomycorrhizal fungus Paxillus involutus with special reference to summer drought, For. Ecol. Manage. 98: 221-228.

[10] Giltrap N.J., Lewis D.H., 1981. Inhibition of growth of ectomycorrhizal fungi in culture by phosphate, New Phytol. 87: 669-675.

[11] Guo X.Z., Bi G.C., 1989. Forest mycorrhiza and its applied technology, Beijing, China Forestry Publishing House Press (in Chinese).

[12] Han G.Y., Qi Y.C., Liu C., Zhou Y.Z., 1993. Effect of temperature and $\mathrm{pH}$ on mycorrhizal fungus growth, China J. Ecol. 12: 15-19 (in Chinese).

[13] Hung L., Tappe J.M., 1983. Growth variation between and within species of ectomycorrhizal fungi in response to $\mathrm{pH}$ in vitro, Mycologia 75: 234-241.

[14] Jefferies R.L. Maron J.L., 1997. The embarrassment of riches: atmospheric deposition of nitrogen and community and ecosystem processes, Trends Ecol. Evol. 12: 74-78.

[15] Jiang F.Q., Zhu J.J., 1993. Development and utilization of sandland from ecological view, Chin. J. Ecol. 12: 44-46 (in Chinese with English abstract).

[16] Jiao S.R., 1989. Structure and function of Mongolian pine plantation for sand fixation in Zhanggutai, Liaoning, Liaoning Science and Technology Press (in Chinese).

[17] Jiao S.R., 2001. Report on the causes of the early decline of Pinus sylvestris var. mongolica shelterbelt and its preventative and control measures in Zhanggutai of Liaoning Province, Sci. Silv. Sini. 37: 131-138 (in Chinese with English abstract).

[18] Johansson J.F., 2002. Belowground ectomycorrhizal community structure along a local nutrient gradient in a boreal forest in Northern Sweden. Swed, Univ. Afric. Sci. Uppsala, pp. 1-26.

[19] Kang H.Z., Zhu J., Xu M.L., 2007. Study on water physiological properties of the artificially-planned saplings of Pinus sylvestris var. mongolica in the Horqin Sandland, Arid Zone Res. 24: 15-22 (in Chinese with English abstract).

[20] Li W.H., 2004. Degradation and restoration of forest ecosystems in China, For. Ecol. Manage. 201: 33-41.

[21] Machado H., Braganca H., 1996. In vitro study of ectomycorrhiza formation under drought stress conditions. In: Proceedings of the fourth European symposium on mycorrhizas, Mycorrhizas in integrated systems from genes to plant development, pp. 455-458.

[22] Marx D.H., 1969. The influence of ectotrophic mycorrhizal fungi on the resistance of pine roots to pathogenic infections. Antagonism of mycorrhizal fungi to root pathogenic fungi and soil bacteria, Phytopathology 59: 153-163.

[23] Michel B.E., 1973. Kaufmann M.R., The osmotic potential of polyethylene glycol 6000, Plant physiol. 51: 914-916.

[24] Mortier F., Le Tacon. F., Garbaye J., 1989. Effect of dose and formulation of Laccaria laccata inoculum on mycorrhizal infection and growth of Douglas fir in a nursery, Agri. Ecosyst. Environ. 28: 351-354.

[25] Nilsen P., Borja I., Knutsen H., Brean R., 1998. Nitrogen and drought effects on ectomycorrhizae of Norway spruce [Picea abies L. (Karst.)], Plant Soil 198: 179-184.

[26] Pampolina N.M., Dell B., Malajczuk N., 2002. Dynamics of ectomycorrhizal fungi in an Eucalyptus globulus plantation: effect of phosphorus fertilization, For. Ecol. Manage. 158: 291-304.
[27] Rincón A., Parladé J., Perab J., 2007. Influence of the fertilisation method in controlled ectomycorrhizal inoculation of two Mediterraean pines, Ann. For. Sci. 64: 577-583.

[28] Sanchez F., Honrubia M., Tores P., 2001. Effects of pH, water stress and temperature on in vitro cultures of ectomycorrhizal fungi from Mediterranean forests, Cryptogamie Mycol. 22: 243-258.

[29] Shi, J.Y., Ding, G.J., 2001. Effects of water stresses on Pinus massoniana seeds from different provenances, J. Mountain Agr. Bio. 19: 332-337 (in Chinese).

[30] Smith S.E., Read D.J., 1997. Mycorrhizal symbiosis. 2nd ed. New York, Academic Press.

[31] Tennakoon M.M.D., Gunatilleke I.A.U.N., Hafeel K.M., Seneviratne G., Gunatilleke C.V.S., Ashton P.M.S., 2005. Ectomycorrhizal colonization and seedling growth of Shorea (Dipterocarpaceae) species in simulated shade environments of a Sri Lankan rain forest, For. Ecol. Manage. 208: 399-405.

[32] Wang S.Q., Xu L.H., Investigation and research of ECM fungi resources of main timber species in northeast, China J. Liaoning For. Sci. Techn. 2 (2002) 17-20 (in Chinese).

[33] Wang X.C., Yan C.X., Chang Z.L., Chen B.J., Wang Q.T., 1999. On intensive management technology of sand-fixation forest for Pinus sylvestris var. mongolica, J. Jilin For. Univ. 15: 60-63 (in Chinese with English abstract).

[34] Wu X.Y., Liu G., Han H., 2002. Soil quality in the different types of Pinus sylvestris var. mongolica man-made sand-fixation forest, J. Beihua Univ (Natural Science) 3: 76-79 (in Chinese with English abstract).

[35] Xu M.L., Zhu J.J., Sun J.D., Kang H.Z., Xu H., Zhang H.W., 2004. A review on the relationships between forest ectomycorrhizal fungi and environmental factors, China J. Ecol. 23: 212-217 (in Chinese with English abstract).

[36] Zhang H.S., Yuan G., Gao G.P., 1992. Pictorial Flora of Macrofungi in the Northeastern shelterbelt, Liaoniang Sci. Tech. Press (in Chinese)

[37] Zhang J.Y., Zhao H.L., Cui J.Y., Zhang T.H., Zhao X.Y., 2005. Community structure, soil water dynamics and community stability of Pinus sylvestris var. mongolica plantation in Horqin sandy land, Sci. Silv. Sini. 41: 1-6 (in Chinese).

[38] Zhao Q., Zeng D.H., Lee D.K., He X.Y., Fan Z.P., Jin Y.H., 2007. Effects of Pinus sylvestris var. mongolica afforestation on soil phosphorus status of the Keerqin Sandy Lands in China, J. Arid Environ. 69: $569-582$.

[39] Zhao Z.P., Guo X.Z., 1989. Ecological studies on ectomycorrhizal fungi in pure cultures, For. Res. 2: 136-141 (in Chinese).

[40] Zhou M.Y., Sharik T.L., Jurgensen M.F., Richter D.L., 1997. Ectomycorrhizal colonization of Quercus rubra seedlings in response to vegetation removals in oak and pine stands, For. Ecol. Manage. 93: 91-99.

[41] Zhu J.J., Fan Z.P., Zeng D.H., Jiang F.Q., Matsuzaki T., 2003. Comparison of stand structure and growth between plantation and natural forests of Pinus sylvestris var. mongolica on sandy land, J. For. Res. 14: 103-111.

[42] Zhu J.J., Zeng D.H., Kang H.Z., Wu X.Y., Fan Z.P., 2005a. Decline of Pinus sylvestris var. mongolica Plantations on Sandy Land. Beijing, China Forestry Publishing House (in Chinese with English abstract).

[43] Zhu J.J., Kang H.Z., Tan H., Xu M.L., Wang J., 2005 b. Regeneration characteristics of natural Mongolia pine (Pinus sylvestris var. mongolica) forests on sandy land in Honghuaerji, J. For. Res. 16: 305-312. 


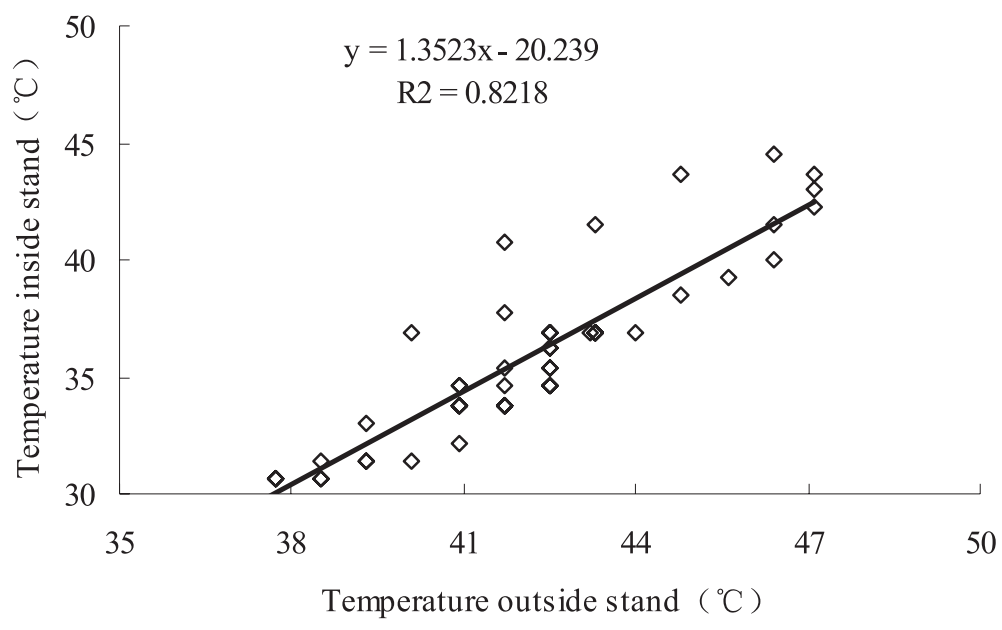

Appendix A. Relationships between temperatures outside and inside plantation stands at $5 \mathrm{~cm}$ soil depth. 